Notes and Queries (2015) 62 (4):553-554.

$10.1093 /$ notesj/gjv187

First published online: December 10, 2015

\title{
SIR JOHN DAVIES AS GUILPIN'S FUSCUS
}

In Everard Guilpin's Skialetheia $(1598)^{1}$ one two-line epigram about someone called Faustus speaks of a poet called Fuscus.

\section{Of Faustus. 19.}

Faustus in steede of grace, saith Fuscus rimes,

Oh gracelesse manners! oh vnhallowed times!

'In steed[e]' is a standard Elizabethan form of 'instead'; thus this epigram says that an admirer of Fuscus says Fuscus's rhymes instead of grace at meals. We know that Fuscus is a popular satirical poet. Guilpin says that he 'taught his Muse to scold' and that '[a]t euery streets end Fuscus rimes are read'. ${ }^{2}$ In his 1868 forward to Skialetheia, John Payne Collier declared 'Marston is ridiculed as Fuscus', but this is guesswork. ${ }^{3}$ Nothing was known of Everard Guilpin when Collier was writing, but we now know that Marston was extremely unlikely to be Guilpin's target. Marston and Guilpin had become step-cousins when Guilpin's mother married Marston's uncle in 1592. Marston dedicated 'Satyra nova' in the 1599 edition of The Scourge of Folly to his 'very friend, Maister E. G.', and 'The Whipper of the Satyr, his Pennance (1601), ascribed to Guilpin, is a defence of Marston's satire' according to the $D N B .{ }^{4}$ No formal scholarly attempt to identify Fuscus has been

\footnotetext{
${ }^{1}$ Everard Guilpin, Skialetheia (London: Nicolas Ling, 1598).

2 Ibid. 'Of Fuscus. 24', and 'To Deloney. 8'.

${ }^{3}$ John Payne Collier, Miscellaneous Tracts, Temp. Eliz. \& Jac. I. (1868), ii.

${ }^{4}$ Philip Hobsbaum. "Guilpin, Everard (B. C.1572)." In Oxford Dictionary of National Biography, ed Lawrence Goldman. (Place Published: Oxford: OUP, 2004), http://www.oxforddnb.com/view/article/72890.
} 
made since 1868, though a trawl of the internet reveals arguments for Fuscus being Thomas Nashe or Christopher Marlowe, with minimal justification. However, Skialetheia contains two further mentions of Fuscus, and one of these, 'Of Fuscus. 24' allows us to identify its target precisely. Ten lines long, the epigram ends:

But how can he a bawdes surname refuse, Who to all sorts thus prostitutes his Muse?

In the Middle Temple's Candlemas revels of 1597/8, John Davies (not yet a knight, but certainly an established writer) became the butt of an elaborate joke; an incident that so incensed him that one week later, he entered the Middle Temple dining room and assaulted his former friend, Richard Martin, with a bastinado. The incident lead to his expulsion and disgrace. Richard Martin, whom Davies counted his 'dearest friend' when he wrote Orchestra (1596), had been voted Prince d'Amour, the Middle Templars' title for the Lord of Misrule. Presumably under his instruction, the festivities culminated in a cruel lampoon of Davies, aimed at both his poetry and his social origins. To the tune of 'The Tanner and the King', Davies - the son of a tanner - was presented with a shield depicting a sphinx and the motto 'Davus sum, non Oedipus', whose meaning, according to J.R.Brink, was 'ignorance of self', a jibe aimed at Davies's poem Nosce Teipsum (Know Thyself). ${ }^{5}$ To this tune, and with this shield, Davies was then 'saluted by the name of Stradilax'. 6

The name Stradilax was derived, apparently, from Davies's habit of 'wadling with his arse out behind'. ${ }^{7}$ The account of eye-witness Benjamin Rudyerd (like Davies, also later knighted) refers to Davies as Stradilax throughout. There is no question, with it's

\footnotetext{
5 J.R. Brink, "The Composition Date of Sir John Davies’ Nosce Teipsum," Huntingdon Library Quarterly 37 (1973): 25 .

${ }^{6}$ P.J. Finkelpearl, "Sir John Davies and the 'Prince D'amour'," Notes \& Queries 10, no. 8 (1963): 301.

${ }^{7}$ John Manningham's diary, cited in Davies, Krueger, and Nemser, The Poems of Sir John Davies, xxxiii. This entry was omitted from the edition of Manningham's diary edited by John Bruce (1868).
} 
implication of 'straddle' and 'laxity', that 'Stradilax' is 'a bawd's name'. There is also no question that John Davies refused it.

Like Davies, who was admitted to the Middle Temple in 1588 and called to the bar in 1585, Guilpin was a lawyer, having entered Gray's Inn in 1591. The story of Davies's Candlemas humiliation and the subsequent violent reaction that led to his expulsion would have been a hot topic of gossip in the Inns of Court in 1598, the year of Skialetheia's publication. It seems reasonable in the circumstances to identify Fuscus as Sir John Davies, and to date 'Of Fuscus. 24' to some time later than February 21598.

ROSALIND BARBER Goldsmiths, University of London. 